\title{
DIVERSITY OF THE TOURISM POTENTIAL AND FUNCTIONS IN THE ROZTOCZE REGION
}

\author{
TERESA BRZEZIŃSKA-WÓJCIK, ${ }^{1}$ EWA SKOWRONEK, ${ }^{2}$ ANDRZEJ ŚWIECA ${ }^{3}$
}

\author{
Uniwersytet Marii Cure-Skłodowskiej \\ Wydział Nauk o Ziemi i Gospodarki Przestrzennej \\ ${ }^{1}$ e-mail: tbrzezin@poczta.umcs.lublin.pl \\ 2 e-mail: ewa.skowronek@poczta.umcs.lublin.pl \\ ${ }^{3}$ e-mail: andrzej.swieca@poczta.umcs.lublin.pl
}

\begin{abstract}
\begin{tabular}{l|l} 
JEL CODES & Z32
\end{tabular}
KEYWORDS tourism potential, tourism function, Roztocze region

ABSTRACT The Roztocze region is characterised by remarkable natural and cultural resources and a relatively well-developed infrastructure. They determine its high educational, recreational, and healthpromoting value. However, the tourism potential of the region is not being fully exploited. The tourism function is irregularly developed on the scale of the entire region. The aim of the article is to present the spatial diversity of tourist phenomena in Roztocze. The objective will be achieved with the use of the taxonomic method of multidimensional comparative analysis. Synthetic measures of the tourism potential and function in communes located in the region were calculated. The values of the indicators suggest that only five units (Krasnobród, Zwierzyniec, Janów Lubelski, Bełżec, Józefów) are characterised by satisfactory and the highest measures. The other communes exhibited disparities in the development of the potential and function. The results of the analysis of the relationships between these measures in the communes have contributed to identification of the current problems of tourism development. They should therefore be taken into account in an attempt at improving the economic situation of the communes through the development of tourism.
\end{abstract}

\section{Introduction}

Roztocze has been regarded as a tourist region since the 30 s of the $20^{\text {th }}$ century (Leszczycki, 1937). A comprehensive review of literature in this field is provided in a paper by BrzezińskaWójcik, Skowronek, Świeca (2016).

The development of tourism in this area has been analysed in detail by e.g. Karolczak (2002), Tucki (2009), Świeca, Brzezińska-Wójcik, Skowronek, Krukowska, Tucki, et al. (2015), and 
Brzezińska-Wójcik et al. (2016). The result of the studies conducted by these authors was a proposal of tourism regionalisation of Roztocze. Despite the differences in the research approaches, all authors considered some elements of the tourism potential and function, which turned out to be important criteria for distinguishing touristic subregions or areas. This finding fits the theoretical assumptions of the concept of a touristic region with the potential and function as its main components (e.g. Liszewski, 2003).

Given the many definitions of the tourism potential analysed by Zajadacz (2004), in this paper, the semantic range of the term was adopted from Naumowicz (1993). As specified by the author, the components of the potential include natural and cultural assets, tourism management, and the activity of local governments to develop tourism and recreation.

The issue of the tourism function, i.e. definition thereof, its semantic range, and methods for determination, has been undertaken by many authors. A comprehensive review of literature in this field is presented in the papers by Fischbach (1989), Derek (2008), Gołembski (2009), and Szromek (2012). With reference to the results reported by these authors, this paper addresses the issues of the size and type of accommodation facilities as well as the intensity of the tourist traffic.

The aim of the article is to present the spatial diversity of tourism phenomena in Roztocze communes. They were expressed by the value of the potential and function measures calculated based on current data. Identification of the correlations between the potential and function in the analysed communes helped to recognise current problems related to the development of tourism. Additionally, it facilitated formulation of recommendations for specific actions that should be undertaken by communes to enhance their economic status through tourism.

\section{Research methods and sources of data}

The image of the spatial diversity of the tourism potential and function in the analysed Roztocze communes (Figure 1) was obtained using the taxonomy method of multidimensional comparative analysis adopted from Gołembski (1999). The research procedure for evaluation of the potential, described in detail by Brzezińska-Wójcik and Skowronek (2017, in press), was based on the number of touristic natural (17 features) and cultural (11 features) assets as well as the tourism material base (14 features). The activity of local governments associated with tourism (3 features) was taken into account as well (Figures 2-3). The tourism function of each analysed commune was evaluated based on two features (the total number of accommodation users and the number of visitors to objects/sites) (Figure 4). Synthetic measures of the components of the potential [(Synthetic Measures of Nature Potential (SMNP), Culture Potential (SMCP), Accommodation Facility Potential (SMAFP), Catering Facility Potential (SMCFP), Transport Accessibility Potential (SMTAP), and Commune Government Activity Potential (SMCGA)] and function [(Synthetics Measures of Total Accommodation Users (SMTAU) and Object/Site Visitors (SMOSV)] were calculated and used for classification of the analysed communes into four classes of tourism potential and function: very high, high, moderate, and low. 


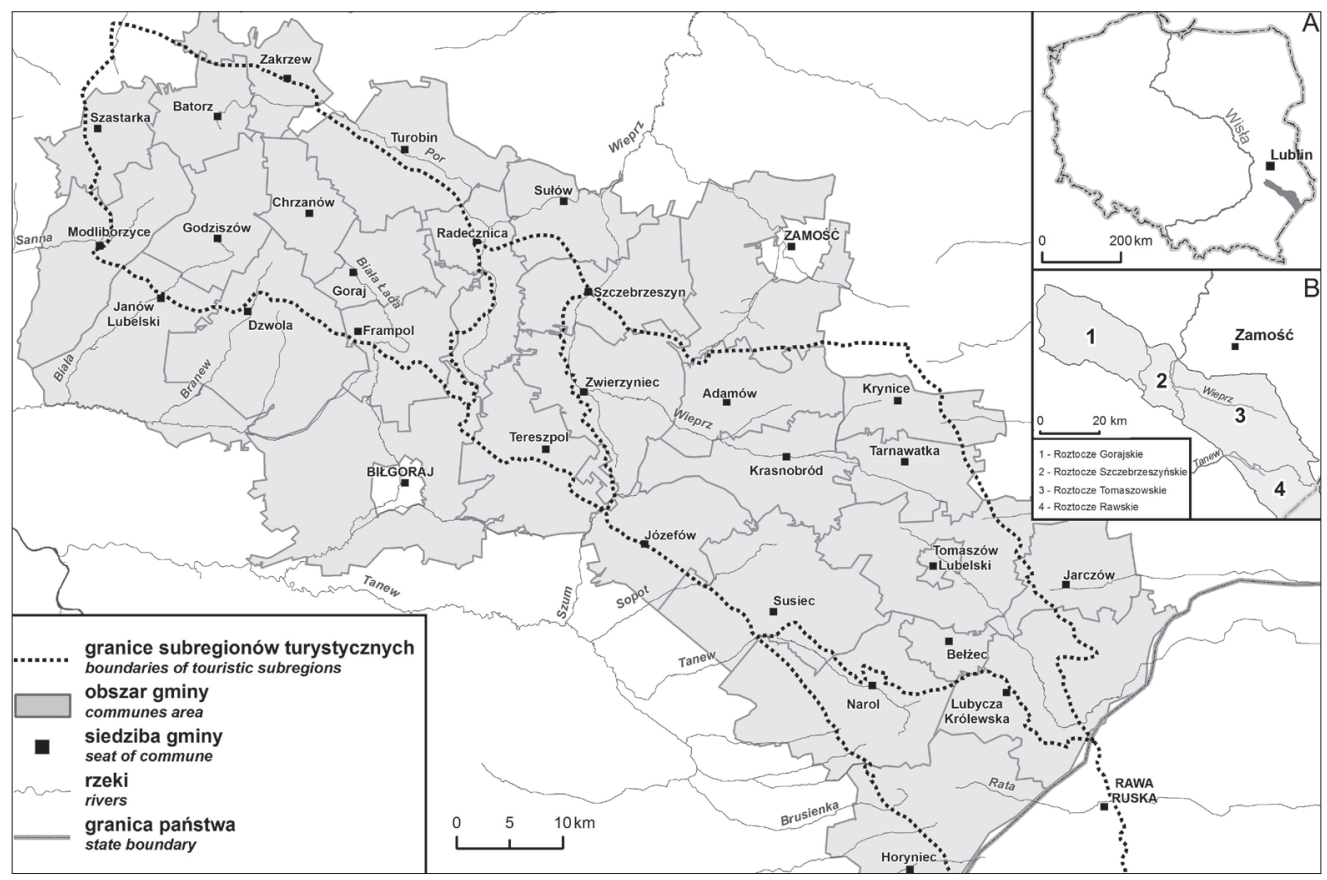

Figure 1. Touristic subregions in Roztocze in relation to the geomorphological units according to Buraczyński (1995)

Source: own investigations, partly based on Brzezińska-Wójcik et al. (2016).

Next, the values of the potential and function measures calculated for the communes using the multidimensional comparative analysis were presented in a two-dimensional space (Figure 5). The space was organised with reference to the arithmetic mean of both general measures - the Synthetic Measure of Tourism Potential (SMTP) and the Synthetic Measure of Tourist Function (SMTF). This allowed distinguishing communes in which: 1) the potential reached the highest values and the function had the lowest values; 2) the function had the highest values and the potential exhibited the lowest values; 3) the potential and function exhibited the lowest values, and 4) the potential and function had the highest values.

The issues addressed in the paper were analysed based on secondary and primary sources of data (Turystyka..., 2016; Turystyka w województwie..., 2016; Bank Danych Lokalnych; stocktaking, query) in 2014-2016.

The analysis of the components of the potential and function was carried out for touristic Roztocze subregions specified by Brzezińska-Wójcik et al. (2016) (Figure 1). 


\section{Diversity of the tourism potential}

The resources of Roztocze that can promote development of various forms of tourism were described in detail by Świeca et al. (2015) and Brzezińska-Wójcik et al. (2016 and literature cited therein).

In this article, the current tourism potential of the region, in accordance with the adopted definition, was evaluated based on the following features: natural and cultural assets, tourism management, and activity of local governments. It was expressed with respective sub-indicators - Synthetic Measures of Nature (SMNP), Culture (SMCP), Accommodation Facility (SMAFP), Catering Facility (SMCFP), Transport Accessibility (SMTAP), and Commune Government Activity (SMCGA) Potentials.

\section{Nature Potential}

The nature potential determining development of tourism in Roztocze is associated with objects of the geological structure, relief, water phenomena, and organic world.

A "very high" potential value (SMNP > 0.073) was assigned to three communes: Bełżec, Krasnobród, and Zwierzyniec, located in Roztocze Tomaszowskie (Figure 2). Bełżec commune is the leader, as its highest value of the measure is associated with the great number of monument trees. The areas of Krasnobród and Zwierzyniec towns and communes are characterised by a high diversity and frequency of occurrence of flora peculiarities, springs, historical parks, and nature collections. In Krasnobród, there are well-known springs (Blessed Virgin Mary's and St. Roch's) flowing from Late Cretaceous rocks, a white chestnut alley, and nature collections in the Museum of Krasnobród Village, Geology, and Pottery. There is a very popular watchtower over an abandoned quarry of Late Cretaceous rocks (with animal and plant fossils). In Zwierzyniec town and commune, the nature collections are displayed in the Education and Museum Centre of the Roztoczański National Park, and geological specimens can be viewed in the Forest Chamber in Florianka. Other well-known assets include the historical "Zamoyski Estate Park" in Zwierzyniec and the Florian pedunculate oak in Florianka.

Communes with a "high" nature potential value (SMNP $=0.026-0.063)$ are represented by Batorz, Szczebrzeszyn, Tarnawatka, Krynice, Józefów, and Narol (Figure 2). In Batorz commune in Roztocze Gorajskie, the major role is played by monument trees and tree groups, geological outcrops and specimens (displayed in the Rural Museum in Batorz), historical parks, and viewpoints. Szczebrzeszyn town and commune located in Roztocze Szczebrzeszyńskie are known for loess gullies, the longitudinal Wieprz River valley, historical parks, viewpoints, and geological specimens in the Museum of Earth and Sea Treasures in Szczebrzeszyn. The "high" potential of Tarnawatka and Krynice communes located in Roztocze Tomaszowskie is mainly related to the presence of monuments of nature and historical parks. In turn, the potential of Józefów commune is associated with the Miocene limestone quarry and the watchtower, Adam Grochowicz Museum of Masonry, Geotouristic Pavilion in Józefów, and a pedunculate oak alley in Górecko Kościelne. Narol commune located in Roztocze Rawskie is famous for the Tanew Rver valley and springs, 
nature reserves, ecological sites, and Wielki Dział, i.e. one of the highest elevations of the entire region.

A

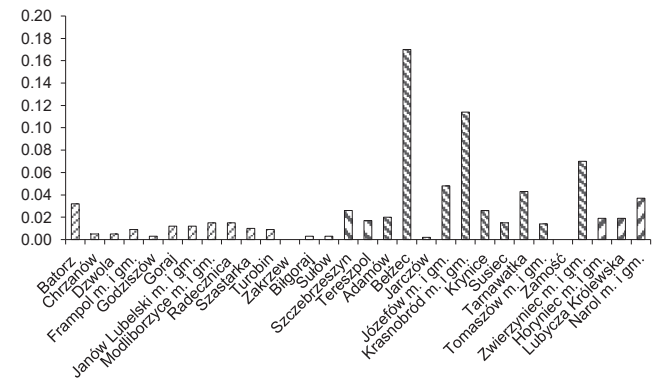

$\mathrm{C}$

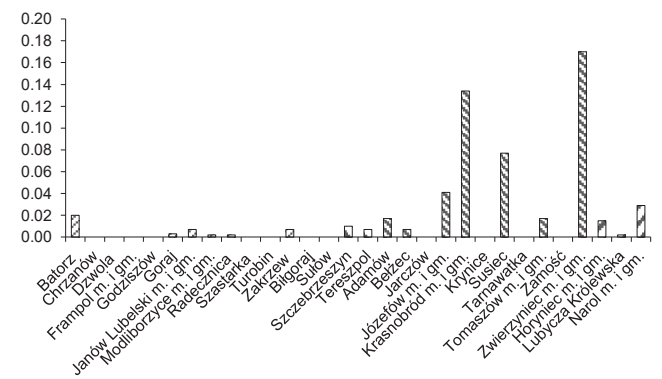

B

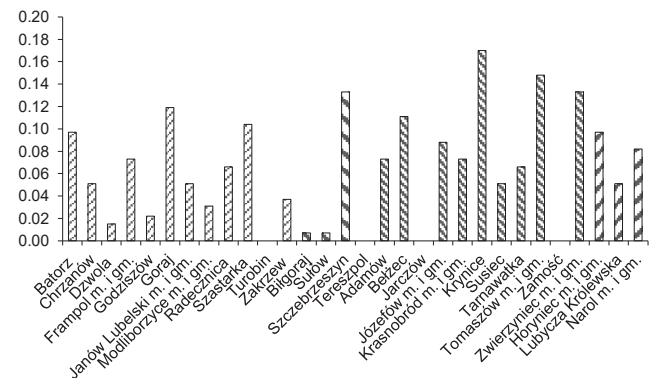

$\mathrm{D}$

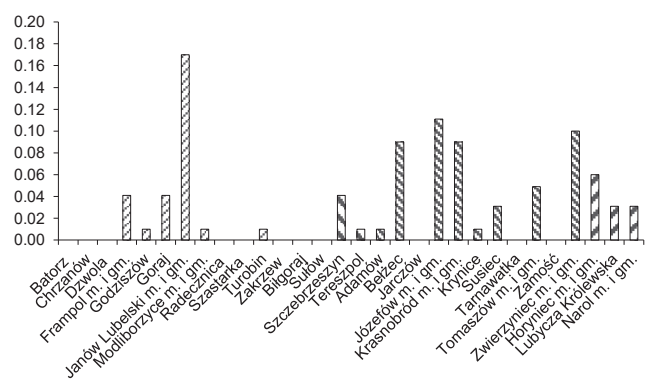

A - nature potential in light of the Synthetic Measure of Nature Potential (SMNP); B - culture potential in light of the Synthetic Measure of Culture Potential (SMCP); C - accommodation facilities in light of the Synthetic Measure of Accommodation Facility Potential (SMAFP); D - catering facilities in light of the Synthetic Measure of Catering Facility Potential (SMCFP).

Figure 2. The diversity of the tourism potential in Roztocze communes

Source: own investigations

Most communes in Roztocze (11) are characterised by a "moderate" potential value (SMNP = 0.010-0.026) (Figure 2). In the Goraj subregion, this group comprises Modliborzyce, Radecznica, Goraj, Szastarka, and Janów Lubelski communes, whose potential is mainly determined by monuments of nature, historical parks, and viewpoints. Radecznica commune is additionally distinguished for the Por River valley springs, in particular St. Anthony's spring. In Janów Lubelski commune, there are Our Lady of Grace springs in the Biała River valley in Janów Lubelski town. The moderate potential of Tereszpol commune in Roztocze Szczebrzeszyńskie is determined by the presence of rocky hills and the viewpoints offered by them. The status of Adamów and Tomaszów Lubelski communes in Roztocze Tomaszowskie is achieved owing to flora peculiarities and historical parks. In turn, Józefów and Susiec communes are assigned their potential based on the presence of springs and knickpoints, i.e. the "thresholds" in the Szum, Sopot, Tanew, and Jeleń 
riverbeds (formed of Late Cretaceous gaizes) and in the Sopot riverbed (formed of Miocene detrital limestone) in the Czartowe Pole reserve.

Horyniec-Zdrój commune, located in Roztocze Rawskie, has sulphate mineral waters (Ciężkowski, Porwisz, Zuber, 2003) used in krenotherapy and balneotherapy as well as peatbog communities (Sobolewska, Sztanke, Pasternak, 2007), which are the basis of the Horyniec-Zdrój spa function. Additionally, there are outcrops of Miocene limestone and sandstone, Miocene caves and rocks, and Świdnica springs (Our Lady Immaculate springs in Nowiny Horynieckie). A unique value on the scale of the country is assigned to silicified fragments of Miocene wood of Taxodioxylon taxodii from the Taxodiaceae family (Kłusek, 2006), which are exhibited in the Museum in Siedliska, Lubycza Królewska commune. In this village, there are also St. Nicholas's springs in the Prutnik River valley.

Communes with a "low" tourism potential value $(\mathrm{SMNP}<0.010)$ are located mainly in the western part of Roztocze (Figure 2). There are single flora peculiarities in six communes of Roztocze Gorajskie, i.e. Frampol, Turobin, Chrzanów, Dzwola, Godziszów, and Zakrzew, Miocene rock outcrops in Biłgoraj commune (Roztocze Szczebrzeszyńskie), and viewpoints in Sułów commune.

\section{Cullure potential}

The analysis of the category of tourist cultural assets determining the potential of Roztocze involved architectural and building monuments, archaeological objects and sites, museums, openair museums, pilgrimage destinations, major battlefields, sites of martyrology, cultural events, and other cultural resources (Skowronek, Kondraciuk, Kosyk-Bilska, 2015; Brzezińska-Wójcik et al., 2016).

Six communes from three subregions, i.e. Goraj, Szczebrzeszyn, and Tomaszów, were classified as having a "very high" value of the Synthetic Measure of Culture Potential (SMCP > 0.102) (Figure 2). The highest values of the parameter in Roztocze Gorajskie were found for Goraj and Szastarka communes. This was determined by the relatively great number of monuments, i.e. chapels and roadside crosses, temples, wooden houses and farmsteads originating from the $19^{\text {th }}$ and $20^{\text {th }}$ centuries, and mills. The potential in Roztocze Szczebrzeszyńskie is attributed to the religious buildings of various religions (Renaissance churches, Greek Catholic church, synagogue) as well as historical public facilities (town hall, school buildings) and industrial buildings (mainly mills) primarily erected by the Zamoyski family in Szczebrzeszyn. Historical mansions, wooden houses, and windmills are preserved in the commune located around the town. In the analysed category of the potential, a majority of communes, i.e. Zwierzyniec, Tomaszów Lubelski, Krynice, and Bełżec, belong to Roztocze Tomaszowskie. The greatest importance in these communes is assigned to sacral objects, palace and court complexes, and technical and industrial facilities (many raised by the Zamoyski Estate). An important object is the Museum - Memorial Site in Bełżec.

In the entire region, the greatest number of communes (9) has been classified to have a "high" potential value (SMCP $=0.065-0.102$ ) (Figure 2). In Roztocze Gorajskie, they are represented by Batorz, Frampol, and Radecznica. In the latter commune, the value of the parameter is related to the 
presence of the many objects of the historical Bernardine monastery complex in Radecznica and wooden mills. The culture potential of Frampol is associated with its unique spatial layout, numerous objects of sacral architecture (church complexes, chapels, and roadside shrines), and remains of wooden manor and farm developments. The potential in Batorz commune is supported by the presence of an early medieval settlement, a church complex, a shrine, a manor house, a wooden farmstead, and a wooden mill. No commune from Roztocze Szczebrzeszyńskie was classified in this category. In Roztocze Tomaszowskie, high values of this indicator were noted for Józefów, Krasnobród, Adamów, and Tarnawatka communes. In this first one, the potential is determined by the historical religious objects related to the pilgrimage centre in Górecko Kościelne as well as the church complex and the synagogue in Józefów, ruins of a paper mill in Hamernia, a complex of Zamoyski Estate historical forester lodges in Florianka and Górecko Stare, and a manor complex in the latter commune. The culture potential in the Krasnobród municipal-rural commune is assigned to the sacral objects of the pilgrimage centre (Dominican monastery complex and chapels in Podklasztor as well as St. Roch's chapel in Zagórze), the palace complex in Krasnobród, and historical $19^{\text {th }}$ and $20^{\text {th }}$ century houses and granges. The value of the SMCP indicator in Adamów commune is primarily influenced by the presence of sacral objects, e.g. the complex of Orthodox churches in Potoczek and Szewnia, the church in Bondyrz, and manor complexes, which play an important role in Niemirówek and Tarnawatka communes as well. The latter administrative unit is characterised by a unique layout of Pańków village (rundling) set up in 1548. The important resources in Tarnawatka include a historical Orthodox church complex, an inn, and a smithy. High values of the culture potential in Roztocze Rawskie were noted in Horyniec-Zdrój and Narol municipal-rural communes. In the former commune, the value of the potential is determined by the Orthodox church complex in Radruż included in the UNESCO list, the historical Poniński palace complex in Horyniec-Zdrój, unique remains of the Basilian monastery in Monastyr, many Orthodox churches and Greek Orthodox cemeteries with historic Brusno tombstones, chapels and roadside crosses, and Molotov Line fortifications. Similar categories of resources are found in Narol commune, where there is also an $18^{\text {th }}$ century palace complex belonging to the Łos family.

"Moderate" potential (SMCP $=0.023-0.065$ ) was assigned to six communes (Figure 2). Four of them, i.e. Chrzanów, Janów Lubelski, Zakrzew, and Modliborzyce, belong to the Goraj subregion. Their rank was determined by the low number of assets such as sacral objects, chapels and roadside crosses, and houses and wooden farmsteads. The most interesting monuments include the Dominican monastery complex and the official buildings of Zamoyski Estate in Janów Lubelski and the $18^{\text {th }}$ century synagogue in Modliborzyce. In Roztocze Tomaszowskie, a moderate value of the potential was noted for Susiec commune. It has only few cultural resources, e.g. the Greek Orthodox church complex in Łosiniec, the church complex in Susiec, and as many as eight $19^{\text {th }}$ and $20^{\text {th }}$ century wooden water mills. In Roztocze Rawskie, the same range of SMCP values was found for Lubycza Królewska commune, which has mainly religious objects, e.g. the Greek Catholic church complexes (Hrebenne, Kornie, Siedliska and ruins in Kniazie and Teniatyska), the church in Lubycza Królewska, and the bunkers of the Molotov Line. 
Eight communes of the regions were characterised by a "low" potential value (SMCP $<0.023$; Figure 2). These are Godziszów, Dzwola, and Turobin in Roztocze Gorajskie and Biłgoraj, Sułów, and Tereszpol in Roztocze Szczebrzeszyńskie. The most recognisable object in this group is the early medieval stronghold in Sąsiadka (Sułów commune). In Roztocze Tomaszowskie, the lowest SMCP values were noted for Jarczów commune and Zamość rural commune.

\section{Tourism management potential}

Accommodation facilities in Roztocze can be found only in 18 administrative units out of 30 . They have been characterised in detail in the review by Świeca et al. (2015).

A "very high" value of the accommodation facility potential expressed by the Synthetic Measure of Accommodation Facility Potential SMAFP $>0.079$ (number of accommodation facilities per unit area) was noted for two communes in Roztocze Tomaszowskie, i.e. Zwierzyniec and Krasnobród (Figure 2). Krasnobród offers the greatest number of accommodations (21.5\% of all accommodation in Roztocze). Both towns and communes offer the greatest numbers of guest rooms.

A "high" value of the potential (SMAFP $=0.018-0.079)$ was noted for four communes: two in Roztocze Tomaszowskie - Susiec and Józefów - and one in Roztocze Gorajskie and Roztocze Rawskie - Batorz and Narol. Agrotourism facilities dominate in Batorz and Józefów communes, whereas guest rooms are predominant in the other units.

A "moderate" potential value (SMAFP $=0.004-0.018$ ) was determined for eight communes: Adamów, Tomaszów Lubelski, and Bełżec in Roztocze Tomaszowskie, Janów Lubelski and Zakrzew in Roztocze Gorajskie, Szczebrzeszyn and Tereszpol in Roztocze Szczebrzeszyńskie, and Horyniec-Zdrój in Roztocze Rawskie (Figure 2). Five communes, i.e. Szczebrzeszyn, Tereszpol, Adamów, Bełżec, and Horyniec-Zdrój, are characterised by the highest number of agrotourism facilities. Collective accommodation facilities dominate in Janów Lubelski town and commune, whereas guest rooms are a majority in Tomaszów Lubelski.

A "low" potential value (SMAFP < 0.004) was found for a majority of the communes, i.e. 16. These are Goraj, Modliborzyce, Radecznica, Chrzanów, Dzwola, Frampol, Godziszów, Szastarka, and Turobin communes in Roztocze Gorajskie, Jarczów, Krynice, Tarnawatka, and Zamość in Roztocze Tomaszowskie, Biłgoraj and Sułów in Roztocze Szczebrzeszyńskie, and Lubycza Królewska in Roztocze Rawskie. Agrotourism facilities dominate in Goraj, Radecznica, and Lubycza Królewska, whereas collective accommodation facilities and guest rooms are most common in Modliborzyce commune.

The catering base complementing the accommodation base in Roztocze comprises over 130 catering facilities. Its structure is dominated by restaurants and bars, and there are relatively many inns (Golian, 2015). It should be emphasised that there are many seasonal catering facilities in the tourist resorts. A majority of them accompany accommodation facilities, which offer additional catering services. The objects are located in 19 of the 30 analysed communes, mostly in towns and holiday resorts. They have been characterised in detail by Świeca et al. (2015). 
Józefów, Zwierzyniec, Bełżec, and Krasnobród communes in Roztocze Tomaszowskie and Janów Lubelski in Roztocze Gorajskie were described by a "very high" value of the catering facility potential (SMCFP > 0.079) (Figure 2).

A "high" value of the catering facility potential (SMCFP $=0.032-0.079)$ was found for Frampol and Goraj communes in the Goraj subregion, Szczebrzeszyn commune in the Szczebrzeszyn subregion, Tomaszów Lubelski commune in the Tomaszów subregion, and Horyniec-Zdrój in the Rawski subregion (Figure 2).

"Moderate" values (SMCFP $=0.008-0.032)$ were assigned to Godziszów, Modliborzyce, and Turobin communes in Roztocze Gorajskie, Susiec, Adamów, and Krynice in Roztocze Tomaszowskie, Lubycza Królewska and Narol in Roztocze Rawskie, and Tereszpol in Roztocze Szczebrzeszyńskie.

The greatest number of communes, i.e. 11, was evaluated as "low" potential (SMCFP $<0.008$ ). They are concentrated mainly in Roztocze Gorajskie, i.e. Batorz, Chrzanów, Dzwola, Radecznica, Szastarka, and Zakrzew. Three communes, i.e. Jarczów, Tarnawatka, and Zamość, are located in Roztocze Tomaszowskie and two - Biłgoraj and Sułów - in Roztocze Szczebrzeszyńskie (Figure 2).

In terms of transport, Roztocze is characterised by good, although spatially varied, external and internal accessibility.

A "very high" value of the transport accessibility potential (Synthetic Measure of Transport Accessibility Potential (SMTAP > 0.114) was reported for Szastarka, Frampol, Goraj, Batorz, and Zakrzew communes in Roztocze Gorajskie and Zamość, Bełżec, Józefów, and Tarnawatka in Roztocze Tomaszowskie (Figure 3). Trunk road 74 connecting Annopol with the border crossing in Zosin runs across Roztocze Gorajskie. The coherence of roads in the longitudinal direction in this subregion is complemented by Lublin-Przemyśl inter-regional road 835. External accessibility in Roztocze Tomaszowskie is provided by a transport artery leading to Ukraine - route S-17. In Roztocze Szczebrzeszyńskie, Sułów commune was assigned such a high value. Roztocze Rawskie was assigned the lowest rank in this aspect.

A

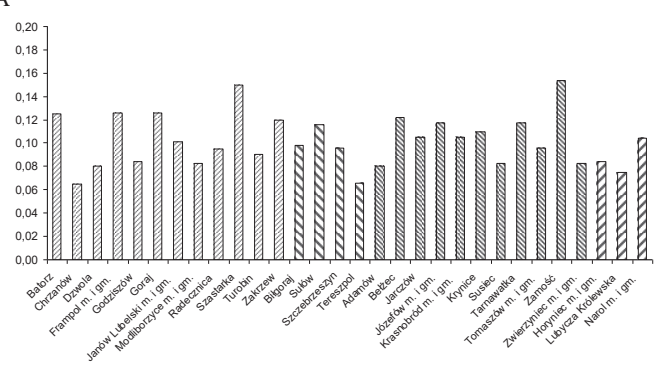

B

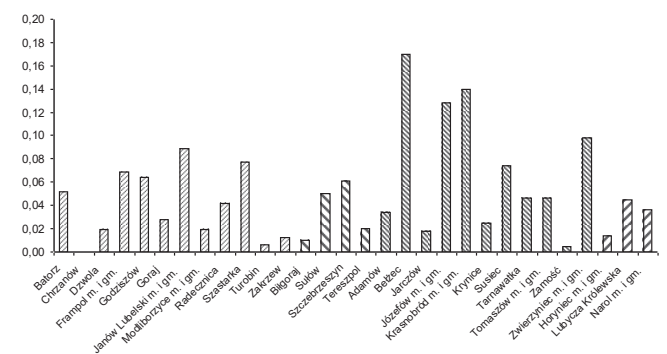

A - transport accessibility in Roztocze communes in light of the Synthetic Measure of Transport Accessibility Potential (SMTAP); B - activity of local governments in Roztocze in light of the Synthetic Measure of Commune Government Activity Potential (SMCGA).

Figure 3. The diversity of the tourism potential in Roztocze communes

Source: own investigations. 
A “high" value (SMTAP $=0.102-0.114)$ was achieved by Roztocze Tomaszowskie communes, i.e. Jarczów, Krasnobród, and Krynice (Figure 3), where route S-17 is located.

A "moderate" (SMTAP $=0.085-0.102)$ potential value was found for Janów Lubelski, Radecznica, and Turobin communes in Roztocze Gorajskie, Szczebrzeszyn, and Biłgoraj in Roztocze Szczebrzeszyńskie, Tomaszów Lubelski in Roztocze Tomaszowskie, and Narol in Roztocze Rawskie.

Communes with "low" potential (SMTAP < 0.085) (Figure 3) constitute a majority. They are concentrated in the central or peripheral parts of the region. The greatest number of such communes, i.e. Dzwola, Godziszów, Modliborzyce, and Chrzanów, are located in the Goraj subregion. A similar number, Adamów, Susiec, and Zwierzyniec, are located in the Tomaszów subregion. A similar value of the potential was found for Horyniec-Zdrój and Lubycza Królewska in the Rawa subregion and for only one commune - Tereszpol - in the Szczebrzeszyn subregion.

Highly important for the border traffic in Roztocze is the border crossing in Hrebenne. Its functioning contributes substantially to the development of accommodation and catering facilities as well as economic growth in transit communes (e.g. Tomaszów Lubelski).

The values of the SMTAP indicator were influenced by data on the internal transport accessibility in Roztocze. The calculations included various routes: cycling trails (e.g. Central Bicycle Route, Green Velo Trail, Zamoyski Estate trail, Bicycle Route to Florianka), hiking trails (Szumy and Krawędziowy trails), and horse riding trails (e.g. Uhlan Horse Trail).

\section{Assessment of the activity of local governments for tourism}

The activity of local governments for tourism in Roztocze was evaluated taking into account the organisation and management of tourism development in the communes as well as promotion, information, and cooperation with the local community.

The group characterised by "very high" values of the Synthetic Measure of Commune Government Activity Potential (SMCGA > 0.089) in all analysed criteria comprises the governments of Bełżec, Krasnobród, Józefów, and Zwierzyniec communes in Roztocze Tomaszowskie (Figure 3). In the field of tourism development, these local governments employ all organisational and promotional instruments. Bełżec commune runs an internet website with an especially legible "tourism" tab, where the basic information in this field is presented very clearly. Krasnobród town and commune have implemented five tourism projects, including one in cooperation with Solec-Zdrój and Rymanów-Zdrój communes. They issue many standard promotional materials, and the two strategic goals adopted are associated with the development and maintenance of the tourism function. Out of the Roztocze communes, Józefów town and commune employ a "tourism animator". Additionally, the commune authorities issue standard materials promoting active (cycling) tourism. The commune website has an extensive "tourism" tab and the commune strategy comprises two goals related to development of infrastructure and the use of the potential of cultural heritage in tourism and recreation. Zwierzyniec town and commune have implemented as many as 11 tourism-oriented projects, which is the greatest number of all Roztocze communes. 
The "tourism" tab on the website is relatively transparent and extensive, and the commune strategy includes two goals associated with development of recreation and gastronomic tourism.

Communes that were assigned a "high" SMCGA value (0.050-0.089) include Janów Lubelski, Szastarka, Frampol, Godziszów, and Batorz in Roztocze Gorajskie, Szczebrzeszyn in Roztocze Szczebrzeszyńskie, and Susiec in Roztocze Tomaszowskie (Figure 3). Janów Lubelski town and commune are the only governments that have adopted a program of development of tourism and recreation specified in a document Strategy for the Janów Lubelski Brand: Nature Zoom. Additionally, the authorities have implemented five tourism projects (e.g. Nature Zoom Recreation Park in 2015); they cooperate actively with the Local Tourism Organisation "Zamość and Roztocze". The local government website is available for tourists. Besides promotion of the touristic values on internet websites, the activity of local governments in Frampol and Godziszów communes is focused on development of tourist infrastructure (Frampol commune was a beneficiary of a project Pięć zalewów - morze atrakcji) and plans for the development of hiking and cycling tourism, as specified in the strategy documents. Szastarka and Batorz communes implement tourism-oriented projects and promote their attractions on their websites. Szczebrzeszyn town and commune support tourism and recreation mainly through the "for tourists" website tab. Additionally, two tourism projects are being implemented to promote the "beetle town" brand. The activities of the local government in Susiec commune are dedicated to tourism-oriented projects associated with the infrastructure around the water reservoir in Majdan Sopocki and development of hiking and cycling routes. Tourist attractions are promoted through standard and online materials.

A "moderate" level of activity (SMCGA $=0.024-0.050)$ was found for Radecznica and Goraj communes in Roztocze Gorajskie, Sułów in Roztocze Szczebrzeszyńskie, Tarnawatka, Tomaszów Lubelski, Adamów, and Krynice in Roztocze Tomaszowskie, and Lubycza Królewska and Narol in Roztocze Rawskie. The activity of local governments is focused on promotion of assets in a standard way and on websites. Lubycza Królewska and Narol are distinguished for their involvement in partnerships and individual projects.

The lowest values of the indicator (SMCGA < 0.024), suggesting "low" activity, were observed in Dzwola, Modliborzyce, Zakrzew, Turobin, and Chrzanów communes in Roztocze Gorajskie, Biłgoraj and Tereszpol in Roztocze Szczebrzeszyńskie, Jarczów and Zamość in Roztocze Tomaszowskie, and Horyniec-Zdrój in Roztocze Rawskie (Figure 3). The activities of the local governments in these communes are limited to promotion of tourist attractions on websites. Horyniec-Zdrój commune have implemented the project of revitalisation of Park Zdrojowy in Horyniec-Zdrój and invested in development of cultural heritage tourism, as specified in the Strategy for the Promotion and Development of the Commune.

\section{Diversity of tourism function}

The tourism function of each analysed commune was assessed based on two synthetic measures: the Synthetic Measure of Total Accommodation Users (SMTAU) and the Synthetic Measure of Object/Site Visitors (SMOSV). 


\section{Tourism function of Roztocze based on the measure of total accommodation users}

Communes with a "very high" index (SMTAU > 0.266) are located in Roztocze Gorajskie and Roztocze Tomaszowskie (Figure 4). Janów Lubelski town and commune in Roztocze Gorajskie are notable, as approximately $91 \%$ of total accommodation users were noted in this subregion. In Roztocze Tomaszowskie, this group is represented by Krasnobród and Tomaszów Lubelski towns and communes with 33\% of total accommodation users (Świeca et al., 2015).
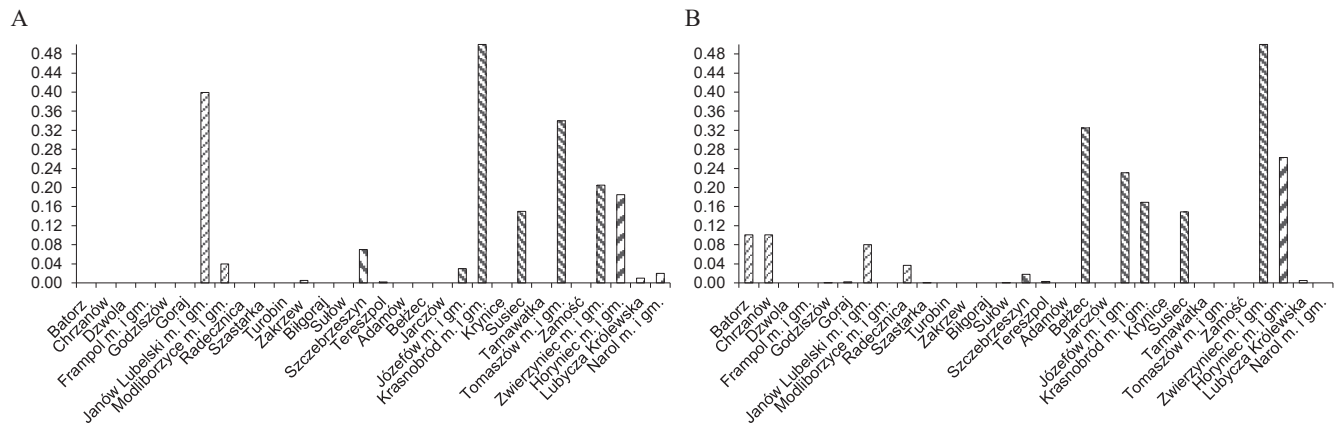

A - based on the Synthetic Measure of Total Accommodation Users (SMTAU); B - based on the Synthetic Measure of Object/Site Visitors (SMOSV)

Figure 4. The diversity of the tourism function in Roztocze communes

Source: own investigations.

A "high" synthetic measure (SMTAU $=0.066-0.266)$ was noted for some towns and communes in Roztocze Szczebrzeszyńskie, Roztocze Tomaszowskie, and Roztocze Rawskie (Figure 4). In Szczebrzeszyn town and commune in Roztocze Szczebrzeszyńskie, as many as $96 \%$ of the estimated total visitors were noted in the subregion. In the Tomaszów subregion, Zwierzyniec and Susiec communes were estimated at $16.6 \%$ and $14.7 \%$, respectively, of total accommodation users visiting Roztocze Tomaszowskie during the year. In Roztocze Rawskie, Horyniec-Zdrój commune was characterised by nearly $87 \%$ of total accommodation users visiting the subregion during the year (Świeca et al., 2015).

A "moderate" level of tourism function development (SMTAU $=0.008-0.066$ ) was achieved by Modliborzyce and Zakrzew communes in Roztocze Gorajskie, Narol and Lubycza Królewska in Roztocze Rawskie, and Józefów in Roztocze Tomaszowskie (Figure 4).

As many as 18 communes, which was the greatest number, were assessed with "low/none" level (SMTAU $<0.008$ ) of development of the tourism function based on the indicator of total accommodation users. 


\section{Tourism function of Roztocze based on the measure of object/site visitors}

A "very high" measure of the tourism function (SMOSV > 0.213) was determined for four units: Zwierzyniec, Bełżec, and Józefów in Roztocze Tomaszowskie and Horyniec-Zdrój in Roztocze Rawskie (Figure 4). In Roztocze Tomaszowskie, the tourist traffic is concentrated mainly in Zwierzyniec and the Roztoczański National Park (approx. 200 thousand visitors per year). The Museum - Memorial Site in Bełżec is visited by 30 thousand tourists with $30 \%$ of foreign tourists, mostly from Israel. The tourist traffic in Józefów commune is estimated at 80 thousand every year. Horyniec-Zdrój commune in Roztocze Rawskie is visited by approximately 150 thousand tourists, mainly spa patients (Brzezińska-Wójcik et al., 2016).

A "high" indicator $(\mathrm{SMOSV}=0.066-0.213)$ was noted for Batorz, Chrzanów, and Janów Lubelski in Roztocze Gorajskie and Krasnobród and Susiec in Roztocze Tomaszowskie (Figure 4). The greatest number of tourists in the Goraj subregion (approx. 40 thousand per year) was noted in Janów Lubelski commune. A similar popularity was noted for Batorz and Chrzanów communes, as approximately 40 thousand ski lift users visit these places in the winter season. In the Tomaszów subregion, Krasnobród and its surroundings are visited by ca. 120 thousand tourists per year. The tourist traffic in Susiec commune is concentrated in the "Szumy nad Tanwią" reserve visited on average by approx. 80 thousand tourists (Brzezińska-Wójcik et al., 2016).

A "moderate" indicator (SMOSV $=0.003-0.066$ ) was noted for Radecznica commune in Roztocze Gorajskie, Szczebrzeszyn and Tereszpol in Roztocze Szczebrzeszyńskie, and Lubycza Królewska in Roztocze Rawskie (Figure 4). Radecznica plays a major role, as it is visited by several thousand pilgrims each year. Szczebrzeszyn is a tourist centre visited by approximately 6 thousand tourists every year. Siedliska located in Lubycza Królewska commune are visited by ca. 2-2.5 thousand tourists per year visiting the Museum of Fossil Trees (Brzezińska-Wójcik et al., 2016).

The greatest number of communes, i.e. 17, were characterised by "low and/or none" tourism function (SMOSV < 0.003) (Figure 4).

\section{Corpelations between the potential and function - summary}

The study results allowed determination of the spatial diversity of the tourism potential and function in Roztocze communes with reference to the arithmetic mean of each of the total indicators. The units were divided into groups characterised by the highest values of the potential and the lowest values of the function, the highest values of the function and the lowest values of the potential, the lowest values of the potential and function, and the highest values of the potential and function (Figure 5).

The values of the total synthetic measures calculated for the administrative units from the first three groups indicate a necessity to take action to improve the tourism status in their area. The low value of the function suggests a need for attracting a greater number of tourists, whereas the low indicator of the potential implies a necessity to improve the tourism offer. In the case of communes representing the fourth group, the relationships between the potential and function are appropriate, which indicates that the available offer is adequate to the needs of the current tourist traffic. 


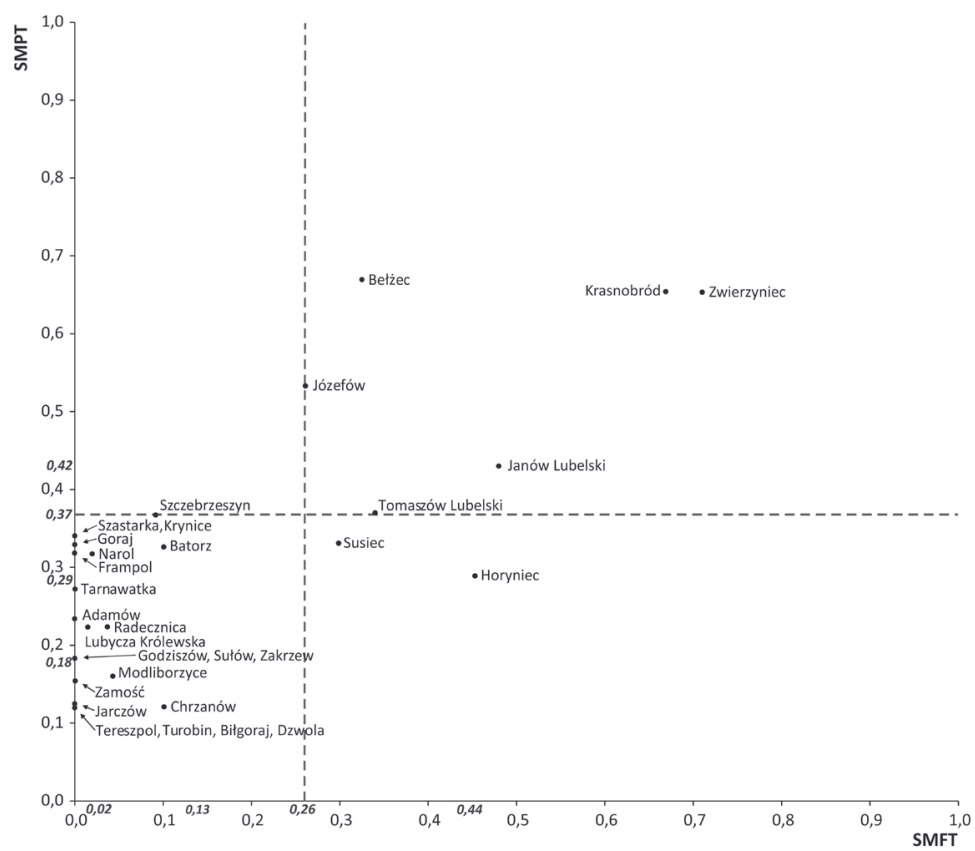

Figure 5. Location of Roztocze communes in the two-dimensional space of total indicators - tourism potential (SMTP) and tourism function (SMTF)

Source: own investigations.

In view of the above results and prospects for tourism development in Roztocze, the communes were divided into 1) units with disparities between the potential and function; 2) units with both relatively low measures, and 3) units with appropriate indicators.

In the first group, indispensable actions that should be taken to ensure balance between the potential and function include:

1. an increase in the number of tourists in communes where the value of the potential exceeds the value of the function. Szczebrzeszyn is an example of such units. Although the town and commune are rich in natural and cultural assets and the local government is active in the field of tourism and recreation, the tourist traffic is low. Therefore, there is a need to develop a tourism offer targeted at a broad spectrum of tourists who will stay in the area for a longer time. To achieve this goal, the resources outside Szczebrzeszyn town should be used. The structure of accommodation and catering facilities as well as promotion of tourism should be improved.

2. development of tourism offer based on available resources in communes where the value of the function exceeds that of the potential, as in Horyniec-Zdrój, Tomaszów Lubelski, and Susiec communes. They are characterised by a relatively well-developed tourist infrastructure fully used by tourists. The problem is the underdeveloped tourism offer, which should make greater use of the existing potential. It is also necessary to increase 
the activity of local governments aimed at promotion of the tourist attractiveness of the communes and to increase the number of tourism entities.

In the case of communes classified into the second group (with relatively low values of both indicators), a broader scope of activities is required. There is a need for intensification and/or undertaking efforts for development of the tourism offer and increasing the number of tourists. This is important, as communes representing this class in Roztocze constitute a majority (21) in the current state of development of tourism-related phenomena (Figure 5). Tourism in the analysed units is usually at the initial stage of development (Świeca et al., 2015). Good transport accessibility and resources of the communes create a possibility of development of an offer that will enhance the intensity of tourism. Intensified activity of local entities and governments in creation of products, development of tourist infrastructure (in particular accommodation and catering facilities), and promotion is indispensable.

Krasnobród, Zwierzyniec, Janów Lubelski, Bełżec, and Józefów represent communes with proper relationships between the potential and function (Figure 5). The first three communities have had a long tradition of tourism activities. Hence, their material base and offer are well developed and used in tourism. This is confirmed by the highest intensity of tourist traffic of all communes in Roztocze.

Bełżec commune has considerable potential; yet, its high rank is determined by the presence of one dynamically operating tourist product (Museum - Memorial Site in Bełżec) and the transit location.

Besides various assets, Józefów commune is outstanding due to the involvement of its local authorities and local community in the development of tourism and recreation. This is reflected in the development of the infrastructure, expansion of the offer, and increasing numbers of tourists.

The communes mentioned above are current leaders compared with all the others. Nevertheless, the entities involved in the tourism offer should be aware of the necessity of upgrading and adaptation of the offer to the changing needs of the tourism market. Only such an attitude will allow maintenance of a satisfactory volume of tourist traffic in subsequent years.

These considerations and suggestions can be considered as recommendations for local entrepreneurs, local governments, and communities designing multifunctional development of their area, including tourism.

The presented image of the current state of tourism facilitates objective assessment of the use of tourist resources in the analysed communes. These important indications/suggestions should be included in strategy documents and actions planned for development of tourism in the Roztocze region.

Translated by Anna Zoń 


\section{Referenences}

Bank Danych Lokalnych. Retrieved from: http://stat.gov.pl/bdl (20.03.2016).

Brzezińska-Wójcik, T., Skowronek, E. (2017) [in press]. Potencjalne i funkcjonalne obszary turystyczne na Roztoczu w świetle wyników wielowymiarowej analizy porównawczej - wyzwania i problemy metodyczne. Prace Geograficzne Instytutu Geografii i Gospodarki Przestrzennej UJ.

Brzezińska-Wójcik, T., Skowronek, E., Świeca, A. (2016). Roztocze - od krainy fizjograficznej do regionu turystycznego. In: T. Brzezińska-Wójcik, E. Skowronek, A. Świeca (eds.), Od regionu geograficznego do regionu turystycznego. Lubelszczyzna - implikacje historyczne, teoretyczne, naukowo-badawcze, edukacyjne (pp. 133-168). Lublin: Wydawnictwo UMCS.

Buraczyński, J. (1995). Regiony geomorfologiczne Roztocza. Annales UMCS, B, 48, 59-73.

Ciężkowski, W., Porwisz, B., Zuber, A. (2003). Geneza i wiek wód siarczkowych Horyńca Zdroju i Ratoszyna. Współczesne Problemy Hydrogeologii, 9 (part 2), 95-102.

Derek, M. (2008). Funkcja turystyczna jako czynnik rozwoju lokalnego w Polsce. A doctoral dissertation written under the scienfitic guidance of prof. dr. hab. Andrzeja Kowalczyka, Wydział Geografii i Studiów Regionalnych Uniwersytet Warszawski. Warszawa. Retrieved from: http://www.zripl.uw.edu.pl/uploads/f_turyzm/1_pdfsam_doktorat $\% 20$ w\%20pdf.pdf (22.01.2016).

Fischbach, J. (1989). Funkcja turystyczna jednostek przestrzennych. Acta Universitatis Lodziensis, Turyzm, 5, 7-26.

Golian, S. (2015). Stan i perspektywy rozwoju agroturystyki na Roztoczu. A doctoral dissertation written under the scienfitic guidance of prof. dr hab. Bogusław Sawicki and dr hab. Ewa Skowronek. Lublin: Wydział Nauk o Ziemi i Gospodarki Przestrzennej UMCS.

Gołembski, G. (ed.) (1999). Regionalne aspekty rozwoju turystyki. Warszawa-Poznań: Wydawnictwo Naukowe PWN.

Karolczak, M. (2002). Przestrzeń turystyczno-wypoczynkowa Roztocza. Turyzm, 1, 5-36.

Kłusek, M. (2006). Fossil wood from the Roztocze region (Miocene, SE Poland) - a tool for palaeoenvironmental reconstruction. Geological Quarterly, 4 (50), 465-474.

Leszczycki, S. (1937). Les régions de l'industrie balnéaire et touristique en Pologne. Bilan du tourisme des villes de cure en Pologne. Acta Balneologica Polonica, 1 (2), 20-25.

Liszewski, S. (2003). Region turystyczny. Turyzm, 1 (13), 43-54.

Naumowicz, K. (1993). Potencjał turystyczny i regionalizacja turystyczna Polski. Rozprawy $i$ Studia Uniwersytetu Szczecińskiego, CCX (136), 165.

Skowronek, E., Kondraciuk, P., Kosyk-Bilska, L. (2015). Materialne dziedzictwo kulturowe. In: T. Grabowski, M. Harasimiuk, B.M. Kaszewski, Y. Kravchuk, B. Lorens, Z. Michalczyk, O. Shabliy (eds.), Roztocze - przyroda i człowiek (pp. 293-310). Zwierzyniec: Wydawnictwo Roztoczański Park Narodowy.

Sobolewska, A., Sztanke, M., Pasternak, K. (2007). Składniki borowiny i jej właściwości lecznicze. Balneologia Polska, 2 (XLIX), 93-98.

Szromek, A.R. (2012). Wskaźniki funkcji turystycznej. Koncepcja wskaźnika funkcji turystycznej i uzdrowiskowej. Gliwice: Wydawnictwo Politechniki Śląskiej.

Świeca, A., Brzezińska-Wójcik, T., Skowronek, E., Krukowska, R., Tucki, A., Grabowski, T., Malska, M., Zinko, J., Brusak, V., Pandiak, I., Shevchuk, O. (2015). Turystyka na Roztoczu. In: T. Grabowski, M. Harasimiuk, B.M. Kaszewski, Y. Kravchuk, B. Lorens, Z. Michalczyk, O. Shabliy (eds.), Roztocze - przyroda i człowiek (pp. 391-427). Zwierzyniec: Wydawnictwo RPN.

Tucki, A. (2009). Propozycja regionalizacji turystycznej województwa lubelskiego. Folia Turistica, 21, 145-164.

Turystyka w 2015 r. (2016). Warszawa: Główny Urząd Statystyczny.

Turystyka w województwie lubelskim w 2015 r. (2016). Lublin: Urząd Statystyczny w Lublinie.

Zajadacz, A. (2004). Potencjał turystyczny miast (na przykładzie wybranych miast Sudetów Zachodnich). Poznań: Wydawnictwo Naukowe Bogucki. 


\section{ZRÓŻNICOWANIE POTENCJAŁU I FUNKCJI W REGIONIE TURYSTYCZNYM ROZTOCZE}

SŁOWA KLUCZOWE

STRESZCZENIE potencjał turystyczny, funkcja turystyczna, Roztocze

Roztocze jest regionem o znaczących zasobach przyrodniczych i kulturowych oraz stosunkowo dobrze rozwiniętej infrastrukturze. Decyduje to o jego wysokiej wartości poznawczej, wypoczynkowej i zdrowotnej. Jego możliwości w zakresie rozwoju różnych form turystyki nie są jednak w pełni wykorzystywane. Nierównomiernie jest też rozwinięta funkcja turystyczna w odniesieniu do całego obszaru. Celem artykułu jest zaprezentowanie przestrzennego zróżnicowania zjawisk turystycznych na Roztoczu. Został on zrealizowany z wykorzystaniem taksonomicznej metody wielowymiarowej analizy porównawczej. Obliczono syntetyczne wielkości potencjału i funkcji turystycznej w gminach położonych w jego granicach. Uzyskane wielkości wskaźników pokazują, że tylko pięć jednostek (Krasnobród, Zwierzyniec, Janów Lubelski, Bełżec, Józefów) osiągnęło zadowalające - najwyższe mierniki. W pozostałych gminach - zaobserwowano dysproporcje w rozwoju potencjału i funkcji. Wyniki analizy relacji pomiędzy tymi wskaźnikami w gminach pozwoliły na określenie aktualnych problemów związanych z rozwojem turystyki. Powinny być one zatem uwzględnione w celu wzmocnienia sytuacji gospodarczej gmin poprzez rozwój turystyki. 